\title{
Factors to Financial Management in Chegutu District Secondary Schools of Mashonaland West Province, Zimbabwe
}

DOI: https://doi.org/10.47175/rielsj.v1ix.141

\section{| Julius Ndhlovu ${ }^{1}$ Lwazi Sibanda', ${ }^{2}$ | Joyce Mathwasa ${ }^{3}$ |}

\author{
1,2Department of Science, \\ Mathematics and \\ Technology Education, \\ National University of \\ Science and Technology, \\ Bulawayo, Zimbabwe \\ ${ }^{3}$ School of General and \\ Continuing Education \\ (SGCE), University of Fort \\ Hare, East London, South \\ Africa.
}

*/wazi.sibanda@nust.ac.zw

\begin{abstract}
The study explored factors that influence financial management in Chegutu District Secondary Schools of Mashonaland West Province, Zimbabwe. The study was stimulated by the serious financial challenges in secondary schools as characterised by failure to follow laid down procedures, disagreements, inadequate training and lack of knowledge by both school heads and SDC members in managing finances. The interpretive paradigm and qualitative approach guided the study. A case study design was adopted and purposively sampled participants constituted five school heads, five School Development Committee chairpersons, five School Development Committee treasurers and five school bursars. Thematically analysed data was collected through semi-structured interviews and document analysis. The findings revealed that manuals and policy circulars influence the way schools formulate their budgets as they give clear steps that should be followed. It also emerged from the study that the school finance committee is responsible for drawing the school budget after consultation with other stakeholders. It was found that training of school heads, School Development Committee members and bursars influence financial management to a larger extent and there is a very strong relationship between financial management training and effectiveness of financial management in secondary schools. The study concluded that good working relationship among stakeholders and lack of knowledge by both school heads and School Development Committee members in managing school finances greatly influence the way they execute their duty of managing school finances. The study recommends further research that explores strategies that can be established for improving the way schools manage finances.

KEYWORDS

Financial management; school finances; secondary schools
\end{abstract}

\section{INTRODUCTION}

The apposite management of finances is fundamental to the success of the operations of any educational institution. This entails making sure that school finances and other resources are effectively, efficiently, economically and transparently utilised. Those in charge should take appropriate steps to prevent any unauthorised, irregular, fruitless and wasteful expenditure ensuring they are accountable for the school's finances (Xaba \& Ngubane, 2010). School managers are, therefore, compelled to meticulously manage school finances with dexterity, care and diligence as all processes depend on their capacity to manage school finances. The emphasis is on school management to possess strong 
financial knowledge and effectively manage all income and expenditure according to financial management principles and practices. According to Kaguri, Njati and Thiaine, (2014) school financial management is the administration of actions by all those in position where achieving desired objectives is imperative. The implication is that, management of school finance involves the tasks such as planning, budgeting, organising, coordinating, leading, communicating and motivating (Kaguri et al., 2014).

Studies have shown that it is the responsibility of school heads working together with School Development Committees (SDC) to manage school finances. In Kenya, a study by Kimani, Munge and Ngugi (2016) revealed that school heads carry out financial management ensuring operational budgets of their schools. Atieno (2013) postulates that in Nigeria, school heads are responsible for managing school finances by identifying short, medium and long term funding priorities and quantify the resources required to accomplish them. Hence, the school head and SDC are expected to carry out proper accounting systems once budgeted funds have been allocated to specific expenditure (Mgandi, Mathuva \& Egondi, 2017).

In Zimbabwe, the Statutory Instrument 87 of 1992 which specifies the role of key players in the school set-up and the involvement of parents through School Development Committees governs the management of school finances (Wushe, Ndlovu \& Shenje 2014). In their study, Mapolisa, Ncube, Tshabalala and Khosa (2014) found that the school heads work as ex-officio members of the SDC and are responsible for budgeting, accounting and auditing functions of financial management. Effective control of school finances ensures that the needs and objectives of the school are catered for, and are realised if correct budgetary procedures are followed (Wushe et al., 2014).

The Ministry of Primary and Secondary Education (MoPSE) has engaged all stakeholders in capacity building programmes to update their knowledge on financial management through modules on management and administration. In 1993, the Better Schools Programme was launched to assist schools with the development of administrative skills and management of financial resources for teachers and school heads. The MoPSE developed a Financial Management Training Manual in pursuit of its Education Sector Strategic Plan for 2016-2020 to strengthen school and system governance (MoPSE, 2015). Through this manual all school administrators are equipped with essential financial management skills to lead in educational institutions (MoPSE, 2015).

In spite of all the training and workshops for school administrators and SDC members, concerns have been raised by teachers, parents, civic society, other stakeholders and observations by various forms of media about mismanagement of finance in schools (Chitumba, 2013; Kachere, 2015; Mapolisa, et al 2014; Samkange, 2013). There is still no clear evidence pertaining to what is really taking place at secondary schools in relation to management of school finances in Chegutu District. With reference to the foregoing discussion, it is in the interest of this study to cross-examine factors that influence financial management in Chegutu District Secondary Schools.

\section{RESEARCH METHODS}

The study adopted the interpretive paradigm because of its strengths derived from its naturalistic approach and dependence on natural forms of human communication (Creswell, 2012). The interpretive research paradigm was chosen because it enabled the researchers to probe deeper into people's behaviours and understanding them better (Nieuwenhuis, 2007). The case study design was selected because it allowed the researchers to visit participants in their natural setting of daily life and obtained an in-depth 
and detailed understanding of the problem under study (Cohen \&Manion, 2011).The study purposively sampled five school heads, five SDC treasurers, five SDC chairpersons and five school bursars. Semi-structured face to face interviews and document analysis were used to collect data which was then thematically analysed.

The use of multiple data sources resulted in triangulation which gave the researchers balanced information from where they could draw conclusions on the phenomenon under study. Furthermore, data credibility was enhanced through thick description analysis of data where the participants' responses were captured verbatim. Throughout the research process, the researchers seriously took cognisance of the ethical issues of informed consent, protection from harm, privacy and confidentiality, as well as honesty.For the purposes of anonymity, the participants were coded as School Heads (SH), School Development Committee Chairperson (SDCC), School Development Committee Treasurers (SDCT) and School Bursars (SB)

\section{RESULTS AND DISCUSSION}

\section{Managing School Finances}

Effective financial management in schools is obligatory to achieve set objectives. Failure to manage school finances might have a negative impact on the development of schools. Ideally, schools should follow set guidelines and policies on managing school finances. The participants' responses were sought regarding questions on how school heads, SDC members and school bursars manage school finances, how MoPSE capacitated school administrators and SDC members in the management of school finances and challenges faced by school heads, SDC members and school bursars in managing school finances.

\section{How School Heads Manage Finances}

School heads play a critical role in financial management and in consultation with key stakeholders they ensure that school funds are effectively and efficiently utilised. The participants responded to how school heads manage school finances. For example, some of the participants responded as follows:

SH1: School heads are responsible for making sure that, firstly, the school budget is drawn by finance committee and approved by responsible authorities. As a school head $l$ am responsible for chairing the finance committee meeting which is made up of myself, deputy head and school bursar, and sign minutes of meeting relating to budgeting.

SH2: As school heads we also monitor the budget by considering the areas such as tuition, sports and building set up in columns so that we do not end up exhausting funds from other columns.

SH3: We follow a procurement process which starts with the finance committee if we want to buy anything. We take at least three quotations and compare then we elect the most appropriate one that meets government requirements. As a school head l am also a member of the finance committee.

SH4: As school heads our role is to audit books of accounts which we usually do at the end of each term to check arithmetical accuracy of books of accounts and physical count of assets. 
On the same issue, the responses from SDC members concurred with school heads as follows:

SDCC1: The school head plays a great role as a members of finance committee responsible in drawing up the school budget. Funds are then disbursed based on this budget.

SDCC2: Theschool head also monitors the budget. He looks at income against expenditure then we prioritise in order to make sure that everything that we planned for need to be achieved.

SDCC4: The school head also performs a greater part in the procurement process. If we want to buy anything, we sit down as a committee and send one to go and collect quotations from three suppliers and we conduct another meeting where we select the best offer then goods can be purchased.

SDCT2: The head is responsible for procuring goods. They sit with departmental heads to prioritise and approve the needs of each department.

SDCT4: It is also the responsibility of the school head to oversee financial statements. The school head performs the duty of internal auditing.

Similarly, the school bursars confirmed previous participants' responses by stating that:

SB1:School heads are responsible for drawing up the school budget. They work together with heads of departments that bring on the table what needs to be bought and they together discuss before procurement considering the availability of funds.

SB2: The school head is also a member of the procurement committee. The procurement committee receives proposals from different departments and they sit down and send someone to get quotations where the committee selects the supplier.

SB3 and SB4: echoed similar sentiments that: The school head performs the duty of internal audit where he/she can audit financial statements at the end of a financial period.

It came out from school heads, SDC members and school bursars that school heads carry out a pivotal role in managing school finances. There is evidence that school heads perform a greater tasks in managing school finances as they participate in drawing up the school budget after making consultation with other stakeholders. School heads also monitor the income and expenditure to see whether what has been budgeted for has been achieved. They also perform the duty of internal auditing where they check books of accounts to ensure accountability.

\section{How School Development Committee Members Manage School Finances}

Like school heads, SDC members are also responsible for managing school finances on behalf of parents who elected them into office. This notion is confirmed in the S.I 87 of 1992 relating to the roles, responsibilities and powers bestowed, which would equip them to function more effectively and efficiently. It is a blue print that guides SDC members in understanding the financial and asset management regulations in their schools in order to improve transparency, accountability and participatory decision making on financial matters. The responses of some of the participants are indicated below. 
SDCC1: As SDC chairperson I am one of the members of finance committee and lam also involved in drawing up the school budget.I also represent parents.

SDCC2: We sit down with other stakeholders and prepare a budget for the coming year on everything that we want to buy as a school.

SDCC5: As SDC chairperson I am also in the finance committee. Our roles are to ensure that what we budget for must be in line with revenue that we receive, so as finance committee we continue managing the budget.

SDCT2: As SDC treasurers we also take part in the procurement process. We sit down with administrators and approve when there are items to be purchased by the school.

The school heads also reiterated in line with SDC members' responses. SH1 states,

SDC members perform the duty of drawing and monitoring the school budget. They make sure fees are used in line with the stated objectives.

SH2 explained,

SDC members also take part in the procurement process. They also endorse by putting their signature if anything need to be purchased. They are also part of the procurement process and we always involve them when planning the process.

Likewise, school bursars confirmed previous participants' responses by stating that:

SB2: SDC members play a great role in managing school finances. Nothing is done that involve finances without engaging them since schools belong to the community. They take part in drawing the budget, monitoring and procurement process as well as auditing books of accounts.

SB3: SDC members are responsible for drawing and presenting the school budget.

The participants' responses illustrate that SDC members play a great part in managing school finances. It is the responsibility of every school to appoint SDC members who represent parents in managing school finances. It has been revealed that SDC members take part in the budgeting process, monitoring the school budget, procurement, management of revenue and also carry out the duty of internal auditing together with managing internal controls.

\section{How School Bursars Manage School Finances}

School bursars play a critical role in managing school finances. They account for finances from receipting, recording, balancing and also posting transactions into the analysis book. The participants were requested to give an account on how school bursars manage school finances and they responded as below:

SH1 and SH2 concurred:

The bursar is like a school accountant who is responsible for collecting funds and issue out the receipt for every payment done to the school. The bursar knows the available funds in the school and they know how much each learner owes in terms of fees to be paid and they issue out invoices at the end of the term indicating the exact amount to be paid. At stated periods they balance the books of accounts indicating income and expenditure. 
Collaborating with school heads, the SDC members affirmed:

SDCC3 stated: At the end of the day the deputy head together with school bursar account for revenue and balance books before putting them into the safe at the end of the day.

The school bursars also expressed similar sentiments showing how they manage school finances.SB4 posits:

My duty is to collect and issue out receipts on a daily basis and at the end of the day I balance off my books before handing over cash to the deputy head for safe-keeping in the strong room. I also sit in the finance committee to advice on the available funds and the guidelines of expenditure.

The responses from participants show that school bursars are responsible for receiving, receipting, invoicing and balancing the books of accounts at the end of the day. A bursar is more like the accountant who is the custodian of school funds although they ultimately are accountable to the school head and SDC chairperson.

\section{Capacitation of School Heads, School Development Committee Members and School Bursars in School Financial Management}

The participants were asked to give their views on how MoPSE capacitate school heads, school bursars and SDC members to manage school finance.

SH2 opined that:

They support the school by bringing officers from accounts department during visits to schools to assist in managing school finances. It is not really a workshop but they check how books are kept and advise where they find loopholes.

Confirming the other colleague's view, $\mathrm{SH} 3$ stated that:

The MoPSE has been able to conduct workshops for the school heads in financial management. Although the school heads do not handle money, they have to know what and how to check and balance the books to avoid pilfering.

SH4 indicated that:

Occasionally officials from the MoPSE conduct training sessions to assist bursars, school heads and SDC members in managing school finances.

Correspondingly, the SDC members affirm what other participants said, as they indicated:

SDCC4: There are manuals and circulars on managing school finances that the ministry sends to schools so that we can refer to for guidance. Training sessions are rarely conducted and they may take place far apart.

SDCT2: They usually assist school administrators most. As for SDC members we are not trained as such but sometimes they conduct refresher courses even so, not done on a regular basis. By nature, our appointments depend on election which make the 
position be on temporary basis, meaning that one may be voted out before attending any workshop.

SDCC3: They help us through training although they are not conducted on regular basis and sometimes they are not favourable because the terminology used is often too difficult for some of us to master the concept.

Collaborating responses came from school bursars who assert that:

SB1: MoPSE sometimes conducts workshops for SDC treasurers and us to acquaint us with knowledge and skills to manage school finances but the chosen parents are not always well educated or proficient in financial terms and ways of bookkeeping.

SB2: Financial workshops are not regularly conducted and sometimes when they take place, insufficient time is allocated such that they fail to improve the financial management skills of school bursars and worse, the SDC treasurer. Hence, the treasurer has to rely on the school head and bursar in managing school funds and drawing up the financial statements to be presented to the parents.

Unveiling information seems to suggest that although MoPSE attempts to use various methods in capacitating school heads, SDC members and school bursars to manage school finances they have very little success in enhancing financial skills to the SDC members. From the responses, MoPSE periodically distributes policy circulars and manuals to help schools in managing finances. However, participants still raise concerns on the way training sessions have been conducted. Other participants lamented lack of consistency in conducting training sessions. Some of the SDC members with low level of education complained about the terminology used which hindered their understanding of financial management concepts.

\section{Challenges Faced by School Heads, SDC Members and Bursars in Managing School Finances}

Regarding challenges experienced by school heads, SDC members and school bursars in managing school finances, responses were as follows:

SH1: Financial management is not included in the training course as a teacher and when one is promoted to headship, inadequate workshops are conducted. We learn through trial and error as we go which makes everything difficult without an accounting background.

SH2: In rural schools, financial management is squarely on the school head and the challenge we have is that parents cannot afford to pay fees in cash preferring to offer their labour which is against the rules of financial management and auditing. Responsible authorities are lagging behind on fees proposals which are not charged in line with the rate of inflation. The intervention of local authorities is essential making proposals and drawing regulations for the parents to adhere to.

SH3: We cannot properly pay up trained bursars so we end up employing individuals with little knowledge in accounting especially in rural areas. Another challenge is that 
SDC members do not understand policies and procedures. Sometimes they want to bring in what they want ignoring what policy says.

SH4: Lack of knowledge due to illiteracy by SDC members is another challenge we face. As school heads we are also not well informed by MoPSE on our responsibility when it comes to management of school finances.

Responses given by school heads indicate that schools face a lot of challenges in managing school finances. Lack of financial management knowledge by school heads becomes a challenge on appointment. It also emerged that in rural schools, parents who cannot afford to pay fees in cash prefer offering their service as payments which is a challenge in equating the service to money for accounting purposes. Participants also highlighted lack of finances to pay qualified bursars resulting in them employing less qualified bursars. It was indicated that the some SDC treasurers' low level of education resulted in lack of understanding financial policies and procedures and caused delays in decision making.

On the same question, SDC members also highlighted their challenges in a different dimension from the school heads and this was the observation:

SDCC1: There is lack of cooperation between school heads and SDC members. Some heads think that they know everything since they are qualified enough. This causes a rift as we feel disrespected.

SDCC2: Some school heads make their own decision without consulting us which we know is against the law. In the workshop we were told that we only sign on agreements. Yes, I agree we do not understand the jargon in accounting but they should explain in simple terms.

SDCT3: Once parents like you they elect you with little education and when we start working in those positions there is scanty training which becomes a challenge on what exactly are we supposed to do as SDC members. We then rely on the school head to tell us what he wants.

Data from the SDC members is symptomatic of challenges faced such as lack of training in what they are supposed to do; low educational level making them fail to understand policies and procedures; lack of cooperation with school heads when it comes to making financial decision-making who often side-line them. All these factors hinder SDC members to fully participate in school financial management.

Information from the bursars collaborate with SDC members when they highlighted lack of cooperation with school heads as the challenge they encounter in managing school finances. Their responses are as follows:

SB1: We are in rural school, sometimes the school head uses money before banking which creates a problem on balancing off books. Another challenge is working with SDC members who have little knowledge on financial policies, income and expenditure procedures, the head overrides their wishes about what to spend the money on, in the end they sometimes absent themselves in crucial meetings where we need their signatures. 
SB3: Incongruities with school heads when it comes to financial matters, lack of knowledge by SDC members affects our job also causing delays in the disbursements of school finances and failure to properly balance off our books is another challenge we face in this school.

SB4: Our biggest challenge in the management of school finances is that school heads often interfere with our work which sometimes brings confusion in the way we conduct our duty. Lack of accounting knowledge by the SDC treasurer makes it worse because they rely on the school head who is able to manipulate decisions in his favour which is sometimes against the financial management policy.

The presented responses show that the school heads, SDC members and school bursars face innumerable challenges mostly due lack of cooperation between school heads and SDC members. Insufficient knowledge on financial policies, income and expenditure procedures by SDC member results in some school heads overriding their decisions on what items are to be procured, which frustrates the SDC members and sometimes end up absenting themselves from crucial meetings where their signatures are required. Responses from participants also indicate that some school heads are using school funds before banking and this has created problems in balancing off financial books in schools. Such practices are against financial management policies provided by MoPSE.

\section{Discussion}

The study established that school heads perform a greater task in managing school finances as they lead the finance committee in drawing up the school budget in consultation with SDC members and other stakeholders. This finding confirms literature observation that it is prudent for the school head to develop a whole-school approach when drawing up a budget where the input of the implementers are considered in coming up with a budget (Ntsele, 2014). It came out from the findings that the school heads also monitor the income and expenditure accounts whether they are in line with the school budget. The findings revealed that school heads perform the duty of internal auditing where they check books of accounts to ensure the proper use of school financial resources. Thus, the current study affirms the revelations that the school head as an accounting financial officer supervises and administers working capital efficiently and economically (Mpolokeng, 2011). Accordingly, the school head manages the school's finances and applies the necessary controls to maximise the use of funds available and to account for all spending (Swartz, 2012).

The findings of the study also indicated that the school bursars are responsible for receiving, receipting, invoicing and balancing the books of accounts at the end of the day. It came out that the bursar is more like the accountant who is the custodian of school funds although they ultimately are accountable to the school head and the SDC.

The study further revealed that although the MoPSE attempts to use various methods in capacitating school heads, SDC members and bursars to manage school finances they have very little success in enhancing financial skills to the SDC members. It emerged that the MoPSE periodically distributes policy circulars and manuals to help schools in managing finances. The finding is in agreement with Swartz (2012) that training in financial management is fundamental in preparing and equipping school managers with financial skills. However, participants in this study still raise concerns on the way training sessions have been conducted. Other participants lamented lack of consistency in conducting training sessions. Some of the SDC members with low level of education complained 
about the terminology used which hindered their understanding of financial management concepts. The findings are consistent with what was found in Nkayi District Secondary Schools by Mapolisa, Ncube, Tshabalala, and Khosa (2014) that officers from the Ministry of Primary and Secondary Education, accounts department were not giving much assistance in guiding school heads and School Development Committees on how to manage school finances.Nevertheless, the findings contradict Swartz's (2012) view that the training should enable the school governing body to be responsible and accountable for funds that have been received for the attainment of specific school objectives. This will also equip them to make a contribution towards the improvement of the overall quality of teaching and learning.

Evidence from the findings revealed that the school heads, SDC members and school bursars face countless challenges mostly due lack of cooperation among school heads and SDC members. Insufficient knowledge on financial policies, income and expenditure procedures by SDC member results in some school heads overriding their decisions on what items are to be procured, which frustrates the SDC members and sometimes end up absenting themselves from crucial meetings where their signatures are required. The findings are commensurate with the results of the study by Mapolisa, et al (2014) that most of the SDC members were illiterate on financial matters and as a result just endorsed the school heads' decisions. The results of the study further confirm that some school heads are using school funds before banking and this has created problems in balancing off financial books in schools. Such practices are against financial management policies provided by MoPSE. Consequently, the finding corresponds with Bua and Adzongo's (2014) observation that poor management of finance results in financial misappropriation, embezzlement and diversion of finance for different projects.

\section{CONCLUSION}

The study examined factors that influence financial management in secondary schools. Based on the findings from this study the researchers concluded that training of both school heads, SDC members and bursars influence financial management to a larger extent and there is a very strong relationship between financial management training and effectiveness of financial management in secondary schools. The study established that, MoPSE influence school heads and SDC members in financial management through; organising training workshops/seminars on financial management, school assessment, advisory visits and auditing/monitoring. The study also established that good working relationship among school heads, SDC members and school bursars greatly influence the way schools manage finances. The study further indicated that lack of knowledge by both school heads and SDC members in managing school finances significantly influence the way they execute their duty of managing school finances.

\section{REFERENCES}

Altieno, N. E. (2013). Factors Influencing Headteachers' Management of Finances in Secondary Schools in Kisumu West District, Kisumu County, Kenya. Unpublished master's dissertation, University of Nairobi, Nairobi, Kenya.

Bua, F. T., \& Adzongo, P. I. (2014). Impact of Financial Management on Secondary School's Administration in Zone A Senatorial District of Benue State-Nigeria. Public Policy and Administration Research, 4(9), 95-103.

Chitumba, R. (2013). School heads facing charges of misappropriation of finance.Sunday Mail Newspaper, p.4. 
Creswell, W. J. (2012). Education Research planning, conducting and evaluation:Qualitative and Quantitative Research. Thousand Oaks: SAGE.

Kachere,V. (2015). Parents raised concern to Ministry of Primary and Secondary Education and recommended for the dismisal of school head and SDC members.The Sunday Mail Newspaper, p. 6.

Kaguri, M., Njati, I. C. \& Thiaine, K. S. (2014). Financial Management Challenges Facing Implementation of Free Day Secondary Education in Imenti North District, Kenya. Journal of Business and Management, 16(1), 55-78.

Kimani, M., Munge.,H \& Ngugi.,D.G. (2016). Factors influencing financial management in public secondary schools in Nakuru District. International Journal of Economics, Commerce and Management, 4 (9), 91-114.

Mapolisa, T., Ncube, A. C., Tshabalala, T., \& Khosa, M. T. (2014). Challenges Faced by School Heads in the Management of School Finances in Nkayi District Secondary Schools. Nova Journal of Humanities and Social Sciences, 3(4), 1-5.

Mgandi, E. N., Mathuva, E., \& Egondi, P. (2017). Factors Influeincing Principal's Financial Management Capability in Public Secondary Schools in Kaloleni and Rabai Sub-counties, Kilifi County. International Journal of Scientific Reserch and Innovative Technology, 4(9), 13-22.

Ministry of Primary and Secondary Education. (2015). Financial management for non finance education managers. Harare: Government Printers.

Mpolokeng, T. E. (2011). The effectiveness of financial mnagement in schools in Lejweleputswa Education District. Unpublished master's dissertation, Central University of Technology, Free State, South Africa.

Nieuwenhuis, J. (2007). Introducing qualitative research. In K. Maree (Ed.), First Steps in Research, (pp. 47-52). Pretoria: Van Schaik Publishers.

Ntsele, C. N. (2014). Accountability and Transparency in Managing School Finances at Primary Schools in Johannesburg South. Unpublished master's dissertation, University of South Africa, Pretoria, South Africa.

Samkange, W. (2013). Management and Administration in Education: What do school heads do? A focus on primary school heads in one district in Zimbabwe.International Journal of Social Sciences and Education, 3(3), 635--643.

Swartz, L. (2012). Financial Management of Schools. Texas: Rice University.

Wushe T., Ndlovu., D \& Shenje.,J. (2014). An Analysis of Basic Management and Financial Skills by School Development Committees (SDC) in Selected Harare Schools. International Journal of Innovative Research in Advanced Engineering, 1(10), 378-386.

Xaba, M., \& Ngubane, D. (2010). Financial Accountability at Schools: Challenges and Implications. Journal of Education, (50), 139-160. 